\title{
Journey of Emancipation in R. K. Narayan's Heroines
}

\author{
Akansha Kayshap Mech \\ 1st year \\ Masters in English \\ CHRIST (Deemed to be University) \\ Delhi, NCR
}

\begin{abstract}
R.K. Narayan conforms to his times and during the period he wrote, there was a radical change in the status of women. Moreover, he maintains an objective detachment from his themes and characters. However detached he is from his characters, it is possible to draw out a conception that the portrayal of women characters takes a definite shape through his novels. As we read his novels, we can trace a gradual transition of his women characters from silence to speech. His pre-independence novels like Swami and Friends, The English Teacher, Dark Room have women who are submissive and docile even though they nurture the desire for liberation. But, R. K. Narayan was a genius to picturise the ordinary middle-class milieu. Narayan takes a different attitude in portraying his post-independence heroines. The middleclass is considered the citadel of tradition but has shown its heroines courageously negotiating their way out from stereotyped notions about women and their roles. His women who are presented as votaries of emancipation educate themselves, long for economic independence and do not hesitate in leaving their parents or dumping their husbands and lovers in their search for individual identity and desired happiness.
\end{abstract}

Keywords- Emancipation, Docile, Education, Independence

\section{Introduction}

In the gallery of women characters portrayed in the novels of R.K. Narayan, we encounter different facets of women. Sometimes, they submit themselves to the dominant discourse for substantiation, and sometimes they favour inner corroboration in search of their 
free selves. It is true that R.K. Narayan conforms to his times and during the period he wrote, there was a radical change in the status of women.

So, it is risky to draw any conclusion from his novels about his point of view and value system. What makes it more difficult is that Narayan seldom comments on his works or is generally reluctant to speak about his inner convictions. But however detached he is from his characters, it is possible to draw out a conception that the portrayal of women characters takes a definite shape through his novels.

R. K. Narayan portrays his women in a kind of realism which is something more than reportage. He grabs the Indian mentality fully with its superstitious comprehension of life, its bewildering contradictions and its sarcastic comic irony. From this novel, it is possible to analyse his attitude towards women and he brilliantly captures the changing scenario in the status of the women with changing time.

In keeping with the middle-class milieu of his novels, Narayan adopts a pedestrian style of portraying his women characters. He has certain unyielding ideas in his mind which we see fully expressed in his novels. The women who are submissive, adopt the community's charted path, feel safer though they live in fear of survival strategy by always battling with their psyche. They derive inner satisfaction in having no need of asserting their own views. To traditional women, matrimony is incomplete without motherhood. Barrenness is a curse for orthodox women. R. K. Narayan's women seldom have strong opinions. They are often judged in relation to the males around them and compared to them; women appear stunted, not fully formed in some of his early novels of the pre-independence era. They work within the confines of home. These women perform their domestic duties mutely.

In a few early novels of R.K. Narayan like The Dark Room, some women characters make certain attempts to go against the prevailing social customs and traditions, but they simply cannot shake them off. They cannot stand the collective force of society as a whole. The result is, they accept defeat, remorse and they find happiness in submission. Narayan does not seem to approve of their attitude or any kind of rebellion on their part. R.K. Narayan's conventional female characters are all doting mothers, loving wives and gorgeous grannies; they may rebel against social exploitations and object to their husband's extramarital affairs, but they are ready for compromise; in no case, they overstep the marriage bonds. 
R. K. Narayan was a genius to picturise the ordinary middle-class milieu. Narayan takes a different attitude in portraying his post-independence heroines. The middle-class is considered the citadel of tradition but has shown its heroines courageously negotiating their way out from stereotyped notions about women and their roles. His women who are presented as votaries of emancipation educate themselves, long for economic independence and do not hesitate in leaving their parents or dumping their husband and lovers in their search for individual identity and desired happiness.

In his journey towards the Painter of Signs, he has shown unflinching devotion to the individuality of Indian women. He has depicted graphically the sense of doubt and identity crisis that his heroes are plunged into as a result of his modern heroines. He has portrayed a panorama of Indian men entangled between traditional notions on the one hand and equally rigid new Indian women on the other desperately endeavouring to discover a way out and strike a balance between the two. To present the reality of Indian society, Narayan shows in his fiction that it is not only women who are cornered for deviating from the traditional trodden path but also men who are questioned and objections are raised if they associate themselves with liberated women. It is not just the problems of women that Narayan has talked about.

Narayan has shown a network of constantly shifting power equations. The dominant female characters use various ways to overcome their handicap. Their struggle to be free from dominance also results in a search for individual identity. The relationships show an inequality based on gender. His novels, therefore, have a powerful political dimension. Kate Millet wrote in Sexual Politics that the essence of politics is power and that the most fundamental and pervasive concept of power in our society is male dominance.

Bharati in Waiting for Mahatma brings a fresh change. The guide represents his more developed testament of feminism and his creation of Daisy in the Painter of Signs marks the climax of his philosophy of woman. It must be admitted here that Narayan's Savitri in The Dark Room, Rosie in The Guide and Daisy in the Painter of Signs are not or rather least educated in the history of feminist movement initiated in the west but as human beings and women of their society, they react against their own predicament in their own ways.

These females prove themselves to be experts in managing various family affairs. In addition to the household chores, Narayan also portrays the resourcefulness of some women who demonstrate considerable attachment to the practicalities of life on this earth. Yet 
historically men did not allow women to use their creative power, the power of ideas as a human being. Women have never held major offices, and even in our own times, the places held by them are negligible enough when compared to those occupied by men. So in the field of decision-making, strategic planning of the world affairs, women have never been a party, and rendering her 'anatomy' as her 'destiny' society has assigned her a passive role of childbearing and child-upbringing while men held all the keys to economic, social and political evolutions of the world.

Initiate her into her destined sphere, the treasures of feminine wisdom are poured into her ears, feminine virtues are urged upon her, she is taught cooking, sewing, housekeeping, along with the care of her person, charms, and modesty (Beauvoir 281-282)

In India, a woman's positions are usually assured in her social role as wife and mother. Traditionally a stigma is attached to bareness. Once she becomes a mother, she acquires prestige and status within the family. Especially, the mother of a male offspring acquires tremendous importance and she is given higher esteem in the family. Social costumes also concentrate on a pregnant woman's feeling of personal well-being. In many parts of India, the expectant mother goes back to stay at her own mother's house a few months before the delivery. This stay helps her to strengthen her identification with her mother, and strengthen her own capacity for motherhood. Narayan's women in the preindependence era seem to be fixed with their stereotypical jobs. They keep themselves busy round the clock serving their husbands, doing everything they can to please them. It seems to be a kind of ritual for them to have their husband eat first, no matter what time they return home. For them eating without serving them seems to be in.

In his Pre-independence novels, Narayan's orthodox background compels him to portray women in their socially assigned roles. They are a set of typical housewives who remain unmoved and satisfied in their boring, monotonous, lifestyle keeping themselves busy with their unpaid jobs. Their world seemed to be confirmed within household chores like cooking, sweeping, and cleaning. The needs of their husbands, children and their in-laws occupy the front seat of their lives. For them, it seemed to be their code of life to get married, bear children and show their expertise in their domestic chores.

The Dark Room can be considered as a sociological study of an Indian household where the husband is always the supreme authority and the wife is expected to obey him. It is a normal thing that takes place in every society where the old double strands are still valid 
and the women are economically so helpless that they just have to limp what they do not like. $\mathrm{He}$ is a breadwinner of the family and hence he expects his wife to be submissive, a 'powerless' and 'voiceless' entity. He firmly believes that a woman has no voice, identity or space in a man's world. As the novelist writes:

She has not the slightest power to do anything at home, and that after fifteen years of married life. Babu did like very ill and she is powerless to keep him in bed, she felt she ought to have asserted herself a title more at the beginning of her married life and then all would have been well (Dark Room, 6)

The rebellion that she feels is limited to her mind but once it is voiced externally she has to face social rejections and is condemned as evil. In literature, women were glorified as goddesses.

Thus, there developed various changes features in an Indian woman of the middle class. The spirit of feminism affected their minds bringing about growth of individualism and a sense of self-respect. In fact, the newly gained freedom has helped Indian women in performing their duties very honestly and sincerely in various spheres of life. These women echo Virginia Woolf's prediction in A Room of One's Own (1929), that in a hundred years, women will have ceased to be the protected sex. Logically they will take part in all the activities and exertions that were once denied them.

\section{Conclusion}

For the people of Malgudi, the institution of marriage matched by horoscopes holds the highest importance. But in R.K. Narayan's later novels are no longer made in heaven. Women's attitude towards marriage has also changed. As a result of economic freedom, women have been able to change the basic rules to some extent. Education had favourably conditioned sex knowledge and practice of family planning which had ushered a new ere to every part of the world and India too was embraced into it. The government sees family welfare as a remedy for almost all social evils like poverty and unemployment.

Other changes are also evident in the post-independent society. Due to increasing individualism and materialism, joint families are breaking up into nuclear ones where the women's position is getting elevated. Education was an instrumental factor in it. But with this change, a wide generation gap is noticed with the emergence of new values. Differences with the elderly people in their opinions are quite visible, for instance, the clash of values of Rosie with Raju's mother Daisy’s feministic views are poles apart from Raman's aunt. 
By presenting these evolutionary trends, and varying feminine perspectives, Narayan gives us the message that in this world of 'Women Empowerment and 'Women's Liberation both tradition and modernity are necessary for the Indian woman. She should keep equanimity and balance between tradition and modernity. If modernity is the need of time, it is our age-old traditions and customs on which our past lies and it is with the strength of tradition that we are what we have become and achieved today.

R.K. Narayan's Female characters grow stronger and justify that the emergence of the 'New Woman' is not a myth or utopia. The new woman of R.K. Narayan has certainly emerged, leaving behind an indelible mark on the Indian psyche. However, this new Malgudi woman is not imported from the west but she has emerged from the age-long rich treasure of Indian culture.

\section{Works Cited}

Acharya, A. Sex, Symbolism, Illusion and Reality in R.K. Narayan's The Guide. Sage Publications, 2003.

Beauvoir, Simone de. The Second Sex. trans. and ed. H.M. Parshley, Vintage, 1997.

Bhatnagar, M.K. New Insights into the Novels of R.K. Narayan. Atlantic Publishers and Distributors (P) Ltd. 2008.

Foucault, Michael. Discipline and Punish. Vintage Books, 1979.

Mill, John Stuart. The Subjection of Women. Women's Liberation and Literature, ed. Elaine Showalter. Harcourt Brace, 1971.

Millett, Kate. Sexual Politics. Abacus Sphere, 1972.

Narayan, R.K. Swami and Friends. Indian Thought Publications, 1994.

- - - . The Bachelor of Arts. Indian Thought Publications, 1965.

- - - . The Dark Room. Indian Thought Publications, 1992.

- - - . The English Teacher. Indian Thought Publications, 1955.

- - - Mr. Sampath - The Printer of Malgudi. Madras: Indian Thought Publications, 1958. Print.

- - - Waiting for Mahatma. Indian Thought Publications, 1964.

- - - . The Guide. Indian Thought Publications, 1958.

Sen, K. Critical Essays on R.K. Narayan's The Guide with an introduction to Narayan's novels. Orient Black Swan, 2004. 
Thwaite, A. "The Painter of Signs”. In: Times Literary Supplement, Jan 20, 1976.

Trivedi, H. "R.K. Narayan at 100", The Journal of Commonwealth Literature, 42:1, 2007.

Wollstonecraft, Mary. A Vindication of the Rights of Women. Everyman, 1982.

Woolf, Virginia. A Room of One’s Own. 1929. Triad Grafton, 1977. 